\title{
Designing Transparency Systems for Medical Care Prices
}

\section{Citation}

Cutler, David, and Leemore Dafny. 2011. “Designing Transparency Systems for Medical Care Prices.” N Engl J Med 364 (10) (March 10): 894-895. doi:10.1056/nejmp1100540.

\section{Published Version}

doi:10.1056/NEJMp1100540

\section{Permanent link}

http://nrs.harvard.edu/urn-3:HUL.InstRepos:26640487

\section{Terms of Use}

This article was downloaded from Harvard University's DASH repository, and is made available under the terms and conditions applicable to Other Posted Material, as set forth at http:// nrs.harvard.edu/urn-3:HUL.InstRepos:dash.current.terms-of-use\#LAA

\section{Share Your Story}

The Harvard community has made this article openly available.

Please share how this access benefits you. Submit a story.

Accessibility 
2. Massachusetts Division of Healthcare Finance and Policy. Measuring healthcare quality and cost in Massachusetts. (http:// www.mass.gov/Eeohhs2/docs/dhcfp/r/pubs/ 09/measuring_hc_quality_cost_mass_ nov-09.pdf.)

3. Waber RL, Shiv B, Carmon Z, Ariely D.
Commercial features of placebo and therapeutic efficacy. JAMA 2008;299:1016-7.

4. Sinaiko $A D$. How do quality information and cost affect patient choice of provider in a tiered network setting? Results from a survey. Health Serv Res 2010 December 9 (Epub ahead of print).
5. HsuJ, Fung V, Price $M$, et al. Medicare beneficiaries' knowledge of Part $D$ prescription drug program benefits and responses to drug costs. JAMA 2008;299:1929-36.

Copyright () 2011 Massachusetts Medical Society.

\title{
Designing Transparency Systems for Medical Care Prices
}

\author{
David Cutler, Ph.D., and Leemore Dafny, Ph.D.
}

Tn the contentious political en-vironment surrounding health care reform, calls for increased price transparency in health care are among the few areas of general agreement. In each of the past 2 years, leading congressional Democrats and Republicans have introduced legislation to mandate price transparency. According to the American Hospital Association, 34 states now require reporting of hospital charges or reimbursement rates, and 7 states provide a forum for voluntary price reporting. The rationale for price transparency is compelling. Without it, how can consumers choose the most efficient providers of care? But though textbook economics argues for access to meaningful information, it does not argue for access to all information. In particular, the wrong kind of transparency could actually harm patients, rather than help them.

A major issue facing transparency systems is what prices to publish. Many proponents of price transparency favor complete disclosure of all prices paid to every provider by every payer for every service. This strategy of openness resonates with a population frustrated by secret deals and payoffs that contribute to escalating costs, and it follows the lead of the Physician Payments Sunshine Act, which will establish a searchable database of all payments from pharmaceutical and device companies to physicians.

Applying the sunshine rule in the provider-payer context, however, could have the opposite of the intended effect: it could actually raise prices charged to patients. To understand why, consider the case in which a wellregarded hospital contracts with two insurers. Suppose the hospital charges a lower price to Insurer 1 because otherwise Insurer 1 would steer patients to a different institution. If the hospital must publicly reveal both prices, it will be less likely to offer the low price to Insurer 1 , because Insurer 2 would then pressure the hospital to lower its price as well. So the sunshine policy would create a perverse incentive for the hospital to raise prices (on average), and as a result its rivals could do the same. This adverse effect of price transparency would arise only in cases in which the buyer or supplier in question had some leverage (market power), but such leverage is fairly common in health care settings, including many local hospital markets.

There is only limited research on the effects of transparency initiatives for medical prices. Two recent studies found no effect of hospital price transparency in New Hampshire or California, but these analyses were (of necessity) limited to 1 or 2 years of post-initiative data., ${ }^{1,2}$ However, the competitive effect of price transparency is akin to that of a frequently employed contractual agreement called a "most-favored nation" (MFN) clause, and the history of such clauses in health care is not encouraging.

Under an MFN arrangement with a particular buyer, a supplier formally agrees not to charge a lower price to any other buyer. If a hospital signed an MFN agreement with Insurer 2, for example, it could not lower its prices to Insurer 1 without also lowering its prices to Insurer 2. Again, prices to Insurer 1 would rise. The MFN clause has a particularly pernicious effect in this setting, because it limits competition among insurers: how can new insurers enter a market if they cannot use innovative models to negotiate lower prices? Indeed, many insurers favor MFN clauses for exactly this reason.

This fear that such arrangements can raise prices is not a matter of idle speculation. The Department of Justice recently filed suit against Blue Cross Blue Shield of Michigan in part because it paid some hospitals higher prices in order to get them to charge its rivals an even higher price, thereby raising prices for everyone. In a case brought by a competitor of Blue Cross Blue Shield of Kansas (Reazin v. Blue Cross and Blue Shield, 
1990), the court considered the insurer's MFN clauses as "evidence of, or . . . contributing to Blue Cross' market or monopoly power." Citing testimony that these MFN clauses "hindered the development of alternative delivery systems, thereby interfering with the introduction of competition," the court upheld the jury's finding of market and monopoly power by Blue Cross Blue Shield. More recently, the Department of Justice approved a hospital-pricegathering initiative by several large employers in California only after confirming that information reported back to a hospital could not be "reverse-engineered" to determine the prices charged by competing hospitals to any particular payer. ${ }^{3}$

Health care is not the only industry in which price transparency and MFN agreements have led to higher prices. In response to concerns that the highly concentrated suppliers of ready-mix concrete were charging widely varying prices to different buyers, Danish antitrust authorities began publishing information on actual invoice prices on a quarterly basis, beginning in October 1993. The result was an increase in average prices of 15 to $20 \%$ within a year, as the lower prices in the market rose and the higher prices edged up. ${ }^{4}$ In the 1960 s and 1970 s, General Electric and Westinghouse guaranteed customers a refund if the same type of turbine they had purchased was sold at a lower price within 6 months after their purchase, and the companies published "price books" showing their spectrum of prices. ${ }^{5}$ The Department of Justice alleged that the pricing policy and book pub- lication were tacit attempts to raise prices. Both companies ultimately suspended these policies as part of a settlement with antitrust authorities.

A number of the price transparency programs for medical care that are currently in place (such as the hospital reporting requirements in Minnesota and Ohio) require providers to report average reimbursements across all payers. By shrouding information about low prices, these programs are less likely to generate the unfavorable consequences described above. However, though these programs may do no harm, they do not give patients information about the prices that they will actually pay for care.

To stimulate price competition, we believe that transparency initiatives should encourage or mandate disclosure of plan-specific patient copayments. Copayments, after all, are what patients actually pay. To make copayment information most salient, it should be presented in a way that reflects and improves upon consumer decision making. As Sinaiko and Rosenthal observe in their Perspective article in this issue of the Journal (pages 891-894), episodebased payments are more helpful than piecemeal reporting, and quality data should accompany prices. Designers of these price menus can do even better by framing information in a way that combats common biases and misperceptions - for example, explicitly addressing people's tendency to overweight the probability of low-likelihood, high-cost events. Thus, prices for births with and without stays in the neonatal intensive care unit could be accom- panied by relative probabilities of these events, ideally tailored to the demographic profile of specific patients.

The effort to promote costconsciousness in health care is both noteworthy and laudable. Just as in other industries, consumers need to know what they are on the hook for when they purchase medical care. But complete transparency of prices negotiated between payers and providers could raise costs instead of lowering them, especially in markets where there is some degree of pricing power and where consumers are imperfect decision makers. As in so much of medical care, the best of intentions can go awry if the plan is not thought through or correctly executed.

Disclosure forms provided by the authors are available with the full text of this article at NEJM.org.

From the Department of Economics, Harvard University (D.C.), and the National Bureau of Economic Research (D.C., L.D.) both in Cambridge, MA; and the Kellogg School of Management, Northwestern University, Evanston, IL (L.D.).

1. Tu HT, Lauer J. Impact of health care price transparency on price variation: the New Hampshire experience. Issue brief no. 128. Washington, DC: Center for Studying Health System Change, 2009.

2. Austin A, Gravelle G. Report for Congress: Does price transparency improve market efficiency? Implications of empirical evidence in other markets for the health sector. Washington, DC: Congressional Research Service, 2008.

3. Letter from Christine A. Varney, Assistant Attorney General, to Mit Spears, Esq., re: Hospital Value Initiative. April 26, 2010. (http://www.justice.gov/atr/public/busreview/ 258013.htm.)

4. Albaek S, Møllgaard P, Overgaard P. Government assisted oligopoly coordination? A concrete case. J Indust Econ 1997;45:42943.

5. Cooper TE. Most-favored-customer pricing and tacit collusion. Rand J Econ 1986;17: 377-88.

Copyright (c) 2011 Massachusetts Medical Society. 